\title{
Status of Honeybee Apismellifera Bandansii Pests and Pathogens in Seka Chokersa District of Jimma Zone, Ethiopia
}

\author{
Desta Abi Gemedi \\ Oromia Agricultural Research Institute (OARI), Adami Tulu Agricultural Research Center (ATARC), Oromia, \\ Ethiopia \\ *Corresponding Author: Desta Abi Gemedi, Oromia Agricultural Research Institute (OARI), Adami \\ Tulu Agricultural Research Center (ATARC), Oromia, Ethiopia
}

\begin{abstract}
A cross-sectional study was conducted in Seka Chokersa district, Ethiopia from November, 2015 to June, 2016 with overall objective of assessing honeybee pests, parasites and pathogens; associated risk factors; and estimating their potential effects on beekeeping. A cluster of 3 beekeeping rural kebeles were randomly taken to select 245 sample beekeepers for questionnaire survey. A total of 60 honeybee colonies were randomly sampled. Semi-structured questionnaire was developed, and pretested for assessing of beekeepers' perception on honeybee pests, parasites, pathogens and associated predisposing conditions. Adult worker bees and bee brood were sampled from the sample honeybee colonies at each season. Samples were analyzed at Bee Protection Laboratory (BPL), Holeta Bee Research Center (HBRC), Ethiopia. Honeybee pests, namely Aethina tumida, Achrolla grisella, Ant spp, Gellaria mellonella, Spiders, Lizards, Bee Eating Birds, Mice and Honey badgers were known to exist in the study area.Comparatively, Aethina tumida, Achrolla grisella and Varroa Destructor were identified the most abundant honeybee pests. Apparent reduction in honeybee population and honey production was observed in the pest affected honeybee colonies. It is suggested that detailed and large scale study be conducted to declare the actual absence of those honeybee pests, parasites and pathogens (which were not tested positive) to help complete these study to the best of its anticipated purpose. It is worth noting that the current research has documented present status for major honeybee pests and parasites in the study area and, therefore can bestow basic information for all stake-takers in designing any of their research and development endeavors with regard to the subsector.
\end{abstract}

Keywords: Honeybee, Pests, Parasites, Seka Chekorsa, Prevalence and Risk factors

\section{INTRODUCTION}

Honeybees are essential organisms that contribute to global nutrition and food security and provide incalculable ecosystem services. However, dramatic increase in abnormal honeybee colony decline in contemporary beekeeping has brought about extensive research and glowed public interest in honeybee health ( Neuman, 2009;Genersch, 2010; Genersch et al, 2010; Rohr et al., 2013). The decline in honeybee numbers is alarming given their important role in ecosystem services and diversification of income (Neumann and Carreck 2010; Vanbergen et al. 2013). The annual colony losses have created problems and bee pollination services have severely hampered, specially, in the western regions (Paudel et al, 2015). Recent studies predict the phenomenon of decline in bee numbers is not restricted to be the problem of western region alone (Jacquetta, 2013). It have been suggested that colony losses do occur in Africa at comparable levels like that of Europe or North America (Wanjama et al (2016). Musyimi (2014) has noted that bee population in East Africa is on the decline.

Several factors have so far been supposed to cause the loss of honeybee in part or in combination (Cepero et al., 2014 ; Eikle \& Olst, 2015; and Maus, 2016). As main cause of the problem, pests, parasites and pathogens are identified (Neumann \& Carreck, 2010; Genersch, 2010; Cepero et al., 2014 ; Eikle \& Olst, 2015; and Maus, 2016).

Studies showed that plethora of honeybee pathogens and pests of temperate origin have been on a pace of spreading out to the tropical climates (Elliud Muliet et al, 2014;Formato \& Smulders, 2016). Most of the pests, parasites and pathogens affecting global honeybee colony health are distributed throughout Africa (Hussein, 2000; Vaudo, et al 2011;Ellis \& Ellis, 2012; Elliud \& Harland, 2014). 
Ethiopia, with over 10 million honeybee colonies has been considered the heart of honey and bees wax production in Africa (Tessega Belie, 2009). Due to its diverse ecological and climatic conditions, the country is home to some of the most copious flora and fauna in the continent ( Agonafir Johannes, 2005 and Tessega Belie, 2009). Its forests and woodlands contain plant species that provide surplus nectar and pollen to foraging bees (Girma Deffar, 1998). The country is estimated to produce 53,000 tons of honey per annum (CSA, 2014), thus shares $23.5 \%$ of Africa's and $2.35 \%$ of world's honey production. This makes the country rank $1^{\text {st }}$ in the continent and $10^{\text {th }}$ in the world (Abel Kebede, 2008).

Despite the tremendous beekeeping resources, in Ethiopia, honey and bees wax production has so far been much more below its annual estimate (Gidey Yirga \& Bethelhem Koru, 2016; Kinati Chala et al, 2012). The general image show that in many beekeeping places, production of honey is unusually shrinking. Benefit from beekeeping sector to the nation and beekeepers has generally been not satisfactory (Tolera Kumsa and Dejene Takele, 2014). Several factors were suggested to have been constraining honeybees and therefore deteriorating beekeeping activity in the country (Yirga Gidey \& Teferi Mekonnen, 2010).

Like in other beekeeping regions, in Ethiopia, honeybees may be affected by myriad of pests and pathogens (Dabessa Jatema \& Belay Abebe, 2015). However, comprehensive information on honeybee health and evidence of diagnosing presence, prevalence and predictable consequences of honeybee pests, parasites and pathogens together with some probable risk factors has been little so far. Available sporadic epidemiological information (Desalegn Begna, 2015), if not absent, has been produced for only few honeybee pests and pathogens in the local honeybees (Desalegn Begna, 2006). Therefore, if basic knowledge on honeybee health constraints in general and status of existing honeybee pests and diseases in particular remain to be missing in the country, future research and decision-making on practical activities on the topic will continue to be deficient. Therefore, with overall purpose of investigating constraints of beekeeping and honeybee health and assessing of honeybee pests and pathogens; associated risk factors; and estimating effect of existence of honeybee pests, parasites and pathogens, a cross-sectional survey was conducted in Seka Chekorsa district of Jimma zone of Oromia Regional State, Ethiopia, from November, 2015 to June, 2016.

The general objective of this research was to assess and diagnose presence and prevalence of honeybee pests and available pathogens at field and laboratory conditions with their associated potential risk factors. In addition, impact on beekeeping due to available honeybee pests and; parasites and pathogens was also predicted.

\section{MATERIALS AND MethodS}

\subsection{Description of the Study Area}

Seka Chekorsa, the current study area is one of the districts in Jimma zone (Figure 3.1), lies in the South Western part of Jimma town, Oromia, Ethiopia. It is located at $07^{\circ} 35^{\prime} \mathrm{N} 36^{\circ} 33^{\prime} \mathrm{E}$. The district is also one of the target area districts of the project, Livestock and Irrigation Value chain for Ethiopian Smallholders (LIVES) under International Livestock Research Institute (ILRI), a project which had funded this study.

Topography of this district ranges from gently sloping to hilly lands with ridges and valleys in between.Located at 12.5Kilometres from Jimma Zone, Seka Chekorsa is bordered on the south by the Gojeb River which separates it from the Southern Nations, Nationalities and Peoples Region; on the west by Gera; on the northwest by Gomma; on the north by Mana; on the northeast by Kersa; and on the east by Dedo. Attitudinally the district extends between 1580 and 2560 masl. It is characterized by three major agro-ecologies viz. Highland "Dega", Midland "woina dega" and Lowland "Kola", (Jimma zone climate profile report, 2007). The mean annual rainfall and temperature of the district ranges $1633-1769 \mathrm{~mm}$ and $16-20^{\circ}$ respectively.) Gojeb, Abono, Gibe, Anja, Gulufa and Meti perennial rivers as well as Harsu and Busho Seasonal streams are flowing through the district. Major soil types found in Seka Chokorsa are Pellic Vertisols, Orthic Acrisols and Dystric Nitosols. High forest, Woodland, riverine and man-made forests are available in the district. Belete Gera forest (37,417 ha) (Meaza Hafiz Abamecha,2015) is under government protection (Ephrem Tesema, 2013). The total surface area of the district is $96.4 \mathrm{~km} 2$ (LIVES, 2008). The rainy season extends from 
February to September with the highest rainfall usually recorded in August. The soil type is dark reddish brown (Abebe Alemu et al, 2011) and the wide area of the region is covered with vegetation (Elias Ayena, 2005).

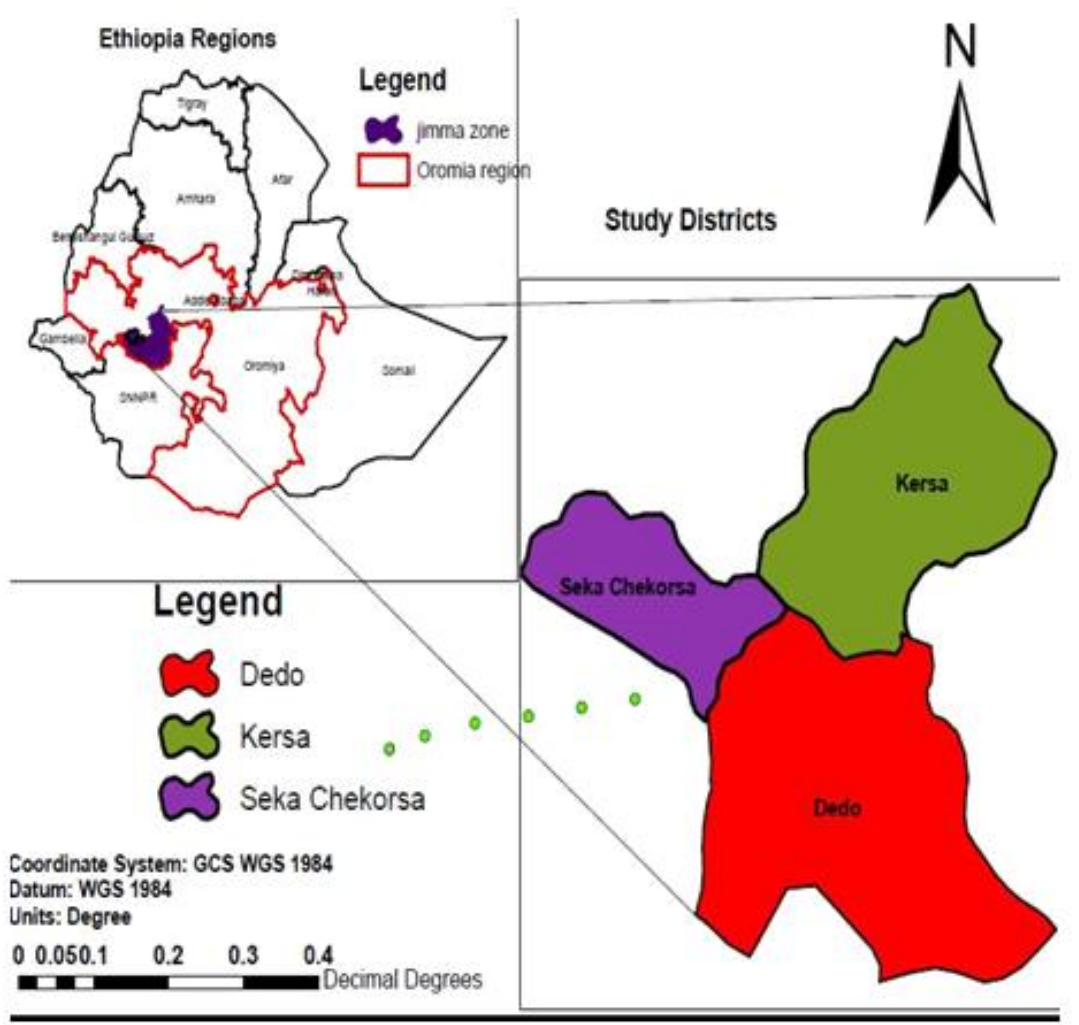

Figure1. Map of location of Seka Chekorsa

\subsection{Study Populations and Sampling Units}

For the purpose of this study, different data were collected from beekeepers, apiaries and honeybee colonies. Secondary data related to beekeepers, honey production and honeybee colonies were collected from Livestock and Fishery Resources Agency (LFRDA) office, Seka Chokersa district via desk discussion with office experts and reviewing of official records. According to official profile of the district, a total number of beekeepers existing had averaged to be 3456. In this study, a cluster of 3 beekeeping rural kebeles were randomly taken to select about 245 beekeepers for questionnaire survey. In this study apiaries were considered valid if and only if they consist of more than ten operational honeybee colonies. Accessibility to the main road, agro ecological representation and willingness of the beekeepers in providing sample honeybee colonies were also considered in the selection of honeybee colony samples. Accordingly, a total of 60 honeybee colonies were randomly sampled from a sample of 15 operational apiaries comprising of 600 established honeybee colonies for diagnostic study of honeybee pests, parasites and pathogens. However, the sample size for apiaries and honeybee colonies could not be estimated in advance of the study and was therefore, subjectively determined based on the likelihood for presence of relevant sampling material for field diagnosis and laboratory studies.

\subsection{Data Collection Methods}

Semi structured questionnaire was prepared and pretested for assessing beekeepers understanding on honeybee pests, pathogens and associated predisposing conditions. From the study district, three data enumerators with relevant expert and experience were chosen and oriented about the type of data to be collected and type of questions incorporated in the questionnaire prior to the commencement of data collection. In this activity, different biological identifications and relevant symptoms of respective honeybee pest, parasite and pathogen diagnosis were reviewed and included in the 
questionnaires. Group discussion and Key Informant Interview techniques of survey data collection were also applied to further understand practical problem of beekeeping as to whether they are related to honeybee pests, parasites and diseases in the district. Different secondary data attributed to honeybee health constraints or honeybee health risk factors were collected. Perceived impacts of the major risk factors were also assessed using the same techniques.

In the selected apiaries, to use sampled honeybee colonies which had been placed in transitional and frame hives on no pay basis, the owners of the hives were convinced in advance of actual field study; their honeybee colonies with traditional hive were used on payment basis.

A seasonal hives inspection and sample bees and bee brood collection was made in each apiary for examination of occurrence for pests, parasites and diseases in each selected apiaries. Sampled apiaries and honeybee colonies were also marked for ease of seasonal data collection. Beekeepers were convinced not to dislocate the selected hives for any purpose, at least, for the study period. In the selected apiaries, inspection of honeybee colonies and sampling of a live worker bees and bee brood (both live and decayed) was carried out during autumn (November, 2015), winter (February, 2016), spring (April, 2016) and summer (June, 2016). However, worker bees and bee brood were collected from the designated hives and used for subsequent laboratory tests. During this time, samples of pests and parasites which were found in or around hives (either alive or dead) were collected for laboratory confirmation.

As was not a well known practice to sample and bring adult alive, without killing from field a new technique was developed in which a wooden box of $3.6 \times 10^{-6}$ cubic meter $(12 \mathrm{mmx} 15 \mathrm{mmx} 20 \mathrm{~mm})$ was constructed to collect worker bees while a $4 \times 10^{-5} \mathrm{~m}^{2}(4 \mathrm{mmx} 10 \mathrm{~mm})$ postal bags for bee brood samples was used to collect brood samples. In this process, bees were made concentrated at the centre in hives where selected brood combs are located. Using bee brush, the bees were brushed off in a bucket, and then about 100 to 200 bees were scooped and put into a wooden boxes which were then covered with a piece of wooden cover and plastered. A $2.5 \times 10^{-5} \mathrm{~m}^{2}(5 \mathrm{mmx} 5 \mathrm{~mm})$ brood area was cut and put in to the postal bags and sealed. During this study, honeybee population and amount of honey produced in each season was also estimated using Lebefielder method as it was used by (Retschnig, 2015). The age (how long have the hive been serving for honey production was also recorded as judged by beekeepers.

Samples were taken to Bee Protection Laboratory, Holeta Bee Research Center (HBRC), and Oromia, Ethiopia for microscopic examinations. Respective standard laboratory protocols which had got accreditation under International organization for Animal Health (OIE) were reviewed and tracked for detection and quantification of honeybee and honeybee pests, parasites and diseases. Major research data like existed honeybee pests, parasites and diseases, season of occurrence, altitude, number of honeybee colonies per apiary, number of sample apiaries, honeybee colony population, and honey produced from infested hives and non-infested hives number of positive samples, and hive types were collected.

\subsection{Method of Data Analysis}

Field and laboratory data were entered into Excel Microsoft office 2003 and Statistical package for social sciences (SPSS) software, version 20 were alternatively used to manage different field and laboratory data in a statistically sound and meaningful manner. All data were manually registered to Excel Microsoft office for edition and cleaning and was partially imported to SPSS based on the type of variables and statistical analysis tools required. In SPSS, different statistical tools and models were used for analysis of different data. Descriptive statics: Index Ranking, Frequency Percentages and ' $F$ ' test were used to assess presence of general honeybee health and beekeeping constraints and prevalence and infestation intensity per individual bee respectively. Seasonal prevalence of different honeybee pests, parasites and diseases was summarized and compared by means of clustered column graphs drawn by a pivot Table procedure of Excel Microsoft office version.2003.To ensure a normal distribution in quantitative datasets, $\log$ transformation was conducted using SPSS soft ware. However, as there was no significant variation in prevalence of existing honeybee pests, parasites and pathogens across different seasons, data was pooled to sixty samples for the subsequent statistical analysis. Comparison of honeybee population growth and honey production in pest free versus pests affected hives was done with the help of line graphs drawn using a pivot graphing procedure of Excel 
Microsoft office. With cross-tabulation procedure/technique of SPSS (versio.20), Pearson-chi-square was used to test association of some potential risk factors: season, altitude, hive type and strength of honeybee colony population to prevalence of a given honeybee pest, parasite and pathogen. And correlation analysis was done and Pearson correlation coefficient was employed to test relation of infestation level of Varroa destructor to different hive variables (age of honeybee colony, honeybee colony population strength to mean infestation of honeybee Varroa destructor.

\section{RESULTS AND DISCUSSION}

\subsection{General Constraints of Beekeeping and Honeybee Health}

In this study, top 9 beekeeping problems were reported (Table 4.1). Presence of honeybee pests and pathogen, prevailing bad weather (prolonged precipitation and freezing and heavy wind speed etc.), Lack of knowledge and skill of honeybee Pest and diseases control, application of agrochemical (direct spray of pesticide on bee visited agricultural crops), Shortage of bee forage, poor or absence of practice of hive shading, Lack of practice of Hive inspection and Shortage of improved hive types were ranked in the decreasing order of their importance. Studies conducted on the topic, in other parts of the country have reported that almost similar problems are affecting honeybee health and beekeeping (Beyene Taye \& Verschuur, 2014; Gidey Yirga et al, 2016). However, the importance of these constraints to honeybee health and beekeeping has been different across studies. Dabessa Jatema and Belay Abebe (2015) has indicated that drought/ water scarcity/, financial problem, pests and predators, poor extension services, shortage of bee forage and high input cost are the most economically important challenges in their decreasing order of importance. Similarly, Yetimwork Gebremeskel et al (2015) has described that the most important constraints in Eastern zone of Tigray were bee forage, pests and predators, beekeeping equipments, absconding, honeybee colony, pesticides and herbicides, death of colony, water shortage, honey storage materials, swarming and marketing. This might be due to other external factors like general climate condition, biogeography and level of beekeeping in particular area. From this evaluation it is evident that beekeeping and honeybee health constraints reported everywhere in the country are present in the study area. Specifically, problems like honeybee pests and predators, occasions of bad weather and application of agrochemicals were much more common to the local beekeeping and honeybees ranking $1^{\text {st }}, 2$ nd and $3^{\text {rd }}$ (Table 4.1) respectively. By the study conducted in Uganda ((Robert Kajobe et al, 2009), it has been identified that honeybee pests and predators are among the top priority problem of beekeeping to be dealt with. Unlike what have been reported in other parts of the country (Gidey Yirga and Bethelhem Koru, 2016), shortage of bee forage and water scarcity was comparatively not as such serious problem in the study area suggesting that improved management of honeybee has to be considered to abate problem of pests and predators, incidence of bad weather and application of agrochemicals.

Table4.1. Index rank of beekeepers response to perceived honeybee health and beekeeping constraints in Seka Chekorsa District

\begin{tabular}{|c|c|c|c|c|c|c|c|c|c|}
\hline \multirow[b]{2}{*}{ Problems } & \multicolumn{7}{|c|}{ Relative degree of importance } & \multirow[b]{2}{*}{ Index } & \multirow[b]{2}{*}{ Rank } \\
\hline & $\mathbf{1}^{\text {st }}$ & $2^{\text {nd }}$ & $3^{\text {rd }}$ & $4^{\text {th }}$ & $5^{\text {th }}$ & $6^{\text {th }}$ & $7^{\text {th }}$ & & \\
\hline $\begin{array}{l}\text { Lack of knowledge and skill of } \\
\text { honeybee pests and diseases } \\
\text { control }\end{array}$ & 35 & 42 & 25 & 16 & 13 & 1 & - & 0.150 & 4 \\
\hline Shortage of bee forage & 4 & 41 & 43 & 11 & 14 & 1 & - & 0.149 & 5 \\
\hline Pests and predators & 150 & 66 & 16 & 10 & 1 & - & - & 0.293 & 1 \\
\hline $\begin{array}{l}\text { Poor or absence of hive inspection } \\
\text { practices }\end{array}$ & 7 & 29 & 13 & 8 & 4 & 5 & - & 0.045 & 7 \\
\hline $\begin{array}{l}\text { Poor or absence of hive shading } \\
\text { practices }\end{array}$ & 20 & 35 & 15 & 26 & 2 & 6 & 2 & 0.099 & 6 \\
\hline Colony death & 2 & 0 & 0 & 2 & - & - & - & 0.007 & 9 \\
\hline $\begin{array}{l}\text { Bad weather (prolonged } \\
\text { precipitation and wind) }\end{array}$ & 0 & 31 & 23 & 65 & 73 & 10 & - & 0.180 & 2 \\
\hline Agro-chemicals & 2 & 22 & 15 & 34 & 73 & 9 & - & 0.179 & 3 \\
\hline $\begin{array}{l}\text { Shortage of improved hive types } \\
\text { and other beekeeping equipments }\end{array}$ & 0 & 0 & 3 & 5 & 6 & 19 & 3 & 0.021 & 8 \\
\hline
\end{tabular}


Index $=\sum(6 *$ for rank $1+5 *$ for rank $2+4 *$ for rank $3+3 *$ for rank $4+2 *$ for rank $5+1 *$ for rank 6$)$ of specific beekeeping problem divided by $=\sum(6 *$ for rank $1+5 *$ for rank $2+4 *$ for rank $3+3 *$ for rank $4+2 *$ for rank $5+1 *$ for rank 6$)$ of all beekeeping problems

\subsection{Honeybee Pests and Predators: A survey summary}

Beekeepers in the study area listed presence of 10 (Table 4.2) different species of honeybee pests and predators. The most common honeybee pests and predators were mentioned to be Aethina tumida ((95.1\%), Achrolla grisella (65.7\%), different species of ants (51\%), Larger Hive Beetle $(42.0 \%)$, Mice (39.1 \%), Bee Eater Birds (27.3\%), Honey badger (18.3\%), Bee Lice (10.2 \%), Spiders (8.9\%) and Lizards $(6.9 \%)$. Existence of nearly all of these honeybee pests and predators have reportedly been existing in every beekeeping regions of the tropics and their importance have been reported by similar studies (Chala Kinati et al, 2012 and Tolera Kumsa and Dejene Takele, 2014) in the country. However,(Yetimwork Gebremeskel, 2015) has reported slightly lower frequencies for existence of different honeybee pests and predators $($ Ants $=18$; Wax Moth $=15.5$; Spider $=10.5$; Honey Badger $=$ 40; Lizard $=4.5$; Snake $=3.5$; and Birds $=8$ ) for Eastern zone of Tigray as compared to finding in the current study. This could be due to a perceived lower importance of honeybee pests and predators in that particular area unlike what is in the current study. Therefore, looking at the proportion of respondents to existence of these honeybee pests and predators, it can be understood that the order of importance of honeybee pests and predators ; and the type of pests and predators existing, as have been reported by previous studies (Jatema \& Abebe, 2015; Kajobe et al., 2009; Nuru Adgaba et al, 2014), is rather different based on location and the level of beekeeping.

Unfortunately, in this survey, none of the sample beekeepers $(0 \%)$ had information on presence of any honeybee parasites and pathogens. This might be due to the fact that local beekeepers are not professionals and had no knowledge of symptom of different parasites and pathogens in their beekeeping activities. Therefore, to get relevant and clear information about honeybee pests in general and honeybee parasites and diseases in particular using local beekeepers perception, and for better management of honeybee health, intensive training is recommended to boost understanding of local beekeepers on nature of the enemies. The occurrence of some of honeybee pests like Aethina tumida, Achrolla grisella and different species of ants suggest detailed study should be undertaken to examine their impact on beekeeping and honeybee production performance where ever they are present.

Table4.2. Beekeepers response percentage on honeybee pests and predators status in Seka Chekorsa District

\begin{tabular}{|l|l|l|}
\hline \multirow{2}{*}{ Pest species } & Response percentage (\%) & Absent \\
\cline { 2 - 3 } & Present & $12(4.8)$ \\
\hline Aethina tumida & $233(95.1)$ & $84(34.3)$ \\
\hline Achrolla grisella & $161(65.7)$ & $65(48.9)$ \\
\hline Ant spp. & $125(51)$ & $142(57.9)$ \\
\hline Oplostomus fluginous & $103(42.0)$ & $220(89.7)$ \\
\hline Braula coeca & $25(10.2)$ & $228(93.0)$ \\
\hline Lizard spp. & $17(6.9)$ & $223(91.0)$ \\
\hline Spider spp. & $22(8.9)$ & $149(60.8)$ \\
\hline Mice spp. & $96(39.1)$ & $178(72.6)$ \\
\hline Bee Eating Bird spp. & $67(27.3)$ & $200(81.6)$ \\
\hline Honey badger spp. & $45(18.3)$ & $245(100)$ \\
Others pests and pathogens & 0 & \\
\hline
\end{tabular}

\subsection{Locally Perceived Effect of Pests and Parasites on Beekeeping}

Perception of local beekeepers was assessed towards negative impact of honeybee pests and predators on honeybee and beekeeping in the current study. Significantly higher proportion of beekeepers (90.2\%) responded that honeybee pests and predators can negatively affect honeybees and beekeeping (Table 4.3). Like $61.6 \%$ and $73.8 \%$ of the sample beekeepers explained that honeybee pests and predators cause absconding and dwindling of honeybees respectively. However, about $10.2 \%$ of the beekeepers viewed that in some cases the presence of honeybee pests and predators might result total death of honeybee. Indeed, the presence of some devastating tropical honeybee pests and predators (Aethina tumida,Achrolla grisella and Varroa destructor) can support the likelihood of total loss of honeybee colonies in local honeybee colonies. Although, few respondents agreed that honey production is constant $(21.6 \%)$ and increasing (13. $8 \%$ ), roughly half percent of respondents (45.7 
$\%$ ) explained honey production is decreased when hive is attacked by pests and predators (Table 4.3). Similar consequences of honeybee pest and predators attack to honeybees and beekeeping were reported to have negative association with honey production (Tolera Kumsa et al, 2014).

Table4.3. Perception of respondents on effect of honeybee pests, parasites and diseases on honeybees and honey production in Seka Chekorsa District

\begin{tabular}{|l|c|c|c|}
\hline Variables & Category & count & \% \\
\hline \multirow{2}{*}{$\begin{array}{l}\text { Impact of pests and } \\
\text { parasites on Honeybee }\end{array}$} & Yes & 121 & 83.4 \\
\cline { 2 - 4 } & No & 24 & 16.6 \\
\hline \multirow{2}{*}{ Impact Type } & Absconding & 51 & 35.2 \\
\cline { 2 - 4 } & Dwindling & 81 & 55.9 \\
\hline $\begin{array}{l}\text { Impact of pests and } \\
\text { predators on Honey } \\
\text { production }\end{array}$ & Death & 13 & 77.2 \\
\cline { 2 - 4 } & Decrease & 112 & 12.4 \\
\cline { 2 - 4 } & Constant & 15 & 10.3 \\
\hline
\end{tabular}

\subsection{Field and Laboratory Diagnosis of Pests and Pathogens}

During this study, honeybee colonies $(n=60)$ were seasonally monitored for presence of honeybee pests, parasites and pathogens. The sampled honeybee colonies were positive (Table 4.4) for two honeybee pests: Aethina tumida (Small Hive Beetle) and Achrola grisella (Lesser Wax Moth); two honeybee parasites: Varroa destructor and Brauala coeca (Bee Lice); and three honeybee pathogens: Ascosporera apis, Nosema apis and Melpighaeamoeba mellificae. None of the diagnosed honeybee colonies were positive for bacterial pathogens: Paenibacillus larvae and Mellisococcus plutonious; fungal pathogen: Aspergillus flavus; and Tracheal mite: Acarapis woodii of honeybees. Indeed, this could not be taken as a concrete reason to report a total absence of these honeybee pests, parasites and diseases with the current research provided that they are rarely incident in African beekeeping. Therefore, it is a good reason to suggest that a more detailed study be conducted in the future to better confirm status of these honeybee parasites and pathogens to make this study complete to the best of its objectives.

In this study, honeybee pests, parasites and pathogens had showed uneven distribution across hive types (Table 4.4). Aethina tumida, Achrola grisella and Varroa destructor were detected in traditional ,transitional and modern hives; whereas Nosema apis and Aschosporeara apis were only tested positive in transitional and modern hives ;Melphigahaeamoeba mellificae in modern hive only ;and Braula coeca in traditional and modern hives only (Table 4.4).In addition, the percentage distribution of all honeybee pests ,parasites and pathogens (Table 4.4) varied from $0 \%$ to $100 \%$ across hive types . Regardless of location, it is likely to suggest that this variation in distribution of the honeybee pests, parasites and pathogens among hive types might be due to factors like level of hive management, source of honeybee colonies and size of apiary.

Table4.4. Percentage distribution of honeybee pests, parasites and pathogens across hive types in Seka Chekorsa District

\begin{tabular}{|c|c|c|c|c|c|}
\hline \multirow{2}{*}{ No. } & \multirow{2}{*}{$\begin{array}{c}\text { Pests, parasites and } \\
\text { pathogens }\end{array}$} & \multicolumn{5}{|c|}{ Hive types } \\
\cline { 3 - 6 } & Atheina tumida & Traditional & Transitional & Modern & \% \\
\hline 1 & N & $\mathbf{P}$ & $\mathbf{P}$ & 66.7 \\
\hline 2 & Achroilla grisella & $\mathbf{P}$ & $\mathbf{P}$ & $\mathbf{P}$ & 100 \\
\hline 3 & Bacillus larvae & $\mathbf{N}$ & $\mathbf{N}$ & $\mathbf{N}$ & 0 \\
\hline 4 & Bacillus pluton & $\mathbf{N}$ & $\mathbf{N}$ & $\mathbf{N}$ & 0 \\
\hline 5 & Nosema ssp & $\mathbf{P}$ & $\mathbf{P}$ & $\mathbf{N}$ & 66.7 \\
\hline 6 & Melphigae mellificae & $\mathbf{P}$ & $\mathbf{P}$ & $\mathbf{P}$ & 100 \\
\hline 7 & Aschosporera apis & $\mathbf{P}$ & $\mathbf{P}$ & $\mathbf{N}$ & 66.7 \\
\hline 8 & Aspergillus flavus & $\mathbf{N}$ & $\mathbf{N}$ & $\mathbf{N}$ & 0 \\
\hline 9 & Varroa spp & $\mathbf{P}$ & $\mathbf{P}$ & $\mathbf{P}$ & 100 \\
\hline 10 & Acarapis Woodii & $\mathbf{N}$ & $\mathbf{N}$ & $\mathbf{N}$ & 0 \\
\hline 11 & Braula coeca & $\mathbf{N}$ & $\mathbf{P}$ & $\mathbf{N}$ & 33.3 \\
\hline 12 & Ant spp & $\mathbf{N}$ & $\mathbf{N}$ & $\mathbf{N}$ & 0 \\
\hline 13 & Others & $\mathbf{N}$ & $\mathbf{N}$ & $\mathbf{N}$ & 0 \\
\hline
\end{tabular}

NB: $P=$ Positive, $N=$ Negative 


\subsection{Seasonal Dynamics of Prevailing Pests and Pathogens}

Seasonal Prevalence of honeybee pests, Aethina tumida and Achoirea gressella; parasites, Varroa destructor and Braula coeca; and pathogens Nosema apis, Melphighaeamoeba mellificae, and Ascosporerae apis was depicted in figure 4.5.1. Among all the diagnosed honeybee colonies, in late autumn (November, 2015) and in mid spring (April, 2016) only Varroa destructor and Aschosporeara apis were tested positive. This report agrees with (Budge et al, 2015) who found 16-35\% and 25.6 $\%$ of varroa destructor and Aschospaera apis detected in collapsing colonies during spring in United Kingdom.

Honeybee colonies were positive in winter (February, 2016) for Aethena tumida (60\%); Varroa destructor (40\%); and Achrolla grisella (40\%). In this season, Braula coeca, Melphighaeamoeba mellificae and Nosema apis were each detected positive with considerable prevalence (20\%). In early Summer (June, 2016), apiaries were positive for Aethina tumida,Achrolla grisella and Varroa destructor with $40 \%$ prevalence. Nosema apis, Melphighaeamoeba mellificae and Aschosporera apis were positive with $20 \%$ prevalence. From this study, it can be concluded that the seasonal prevalence for Aethina tumida (60\%), Achrolla grisella (40\%), Varroa destructor (40\%); and Nosema apis, and Braula Coeca $20 \%$ peaked during winter across apiaries. Existence of Varroa mite during this season might be due to the fact that in the study area there are sufficient flowering plants that provide surplus feed material (pollen) for honeybee that help continuous brooding activity of honeybee colonies. The population growth of Varroa is affected by the amount and type of brood, and the post capping period of the brood cell (Fabiana et al 2014).

In Ethiopia, Aethina tumida was recognized as local honey bee parasite in two honey flow seasons in the south and south-west parts, in $37.5 \%$ of colony bee with prevalence rate of $10 \%$ Amssalu Bezabeh and Desalegn Begna (2008) reviewed in (Haylegebriel Tesfay, 2014) .The pest was reported in the maize and coffee growing regions of Oromia regional state; Jimma, Illu Abbabora, Horo Guduru, Wollega, East Wollega and Western Showa. The highest infestation and distribution of the pest was also reported in Jimma (60\% and $83.9 \%$ and $5.3 \%$ and $1.1 \%$ in Horo Guduru. Similarly it was reported in six districts; Mega, Moyale, Teltele, Konso, Key-Afer and Segen in the South and Southern parts of Ethiopia with prevalence rate infection ranges from $21 \%$ in Konso to $66 \%$ in Teltele.

The seasonal dynamics of honeybee pests, Aethina tumida,Achrolla grisella and Braula coeca; parasites, Varroa destructor ; and pathogens, Aschosporera apis, Nosema Apis and Melphighaeamoeba mellificae were shown to be different across seasons. The colony level prevalence for Varroa destructor was relatively higher during autumn and spring seasons peaking at April and lower during pollen dearth seasons of the year (winter and summer).Different authors have reported that seasonal variation is directly correlated with the growth Varroa destructor population (Allsopp, 2006; Kamran, 2001; Okosun, 2013). On the contrary, honeybee pests, Aethina tumida and Achrola grisella were shown to be severely found in honeybee colonies during pollen dearth seasons of the year. This report agrees with (Tarpy. et al, 1998 ;Bronisław et al, 2000; Etsay., 2015) who have reported that $84 \%$ of the modern hives with colonies had visible larval stage of wax moth during pollen dearth seasons of the year in different places .In this study, the prevalence of Nosema apis, Melphighaeamoeba mellificae and Aschosporera apis and Braula coeca were slightly lower and seemingly less affected by seasonal variation. Generally, the highest severity level was attained during dry seasons for those honeybee pests and parasites. The fact that these pests have higher prevalence than the others might be due to inherent/opportunistic ability of the honeybee pests to infest honeybee colonies over the others. Or else, it can be determined by a pest specific resistance mechanism of honeybee colonies. However, which of the reasons determine prevalence of these honeybee pests, parasites and diseases is beyond the scope of this study. Future research should make clear as to what are the factors that determine asymmetrical prevalence among different honeybee pests and pathogens. Therefore, future research and beekeeping development activities should focus on mechanisms of controlling honeybee pests and parasites for better production and productivity of honeybees in the study area. 


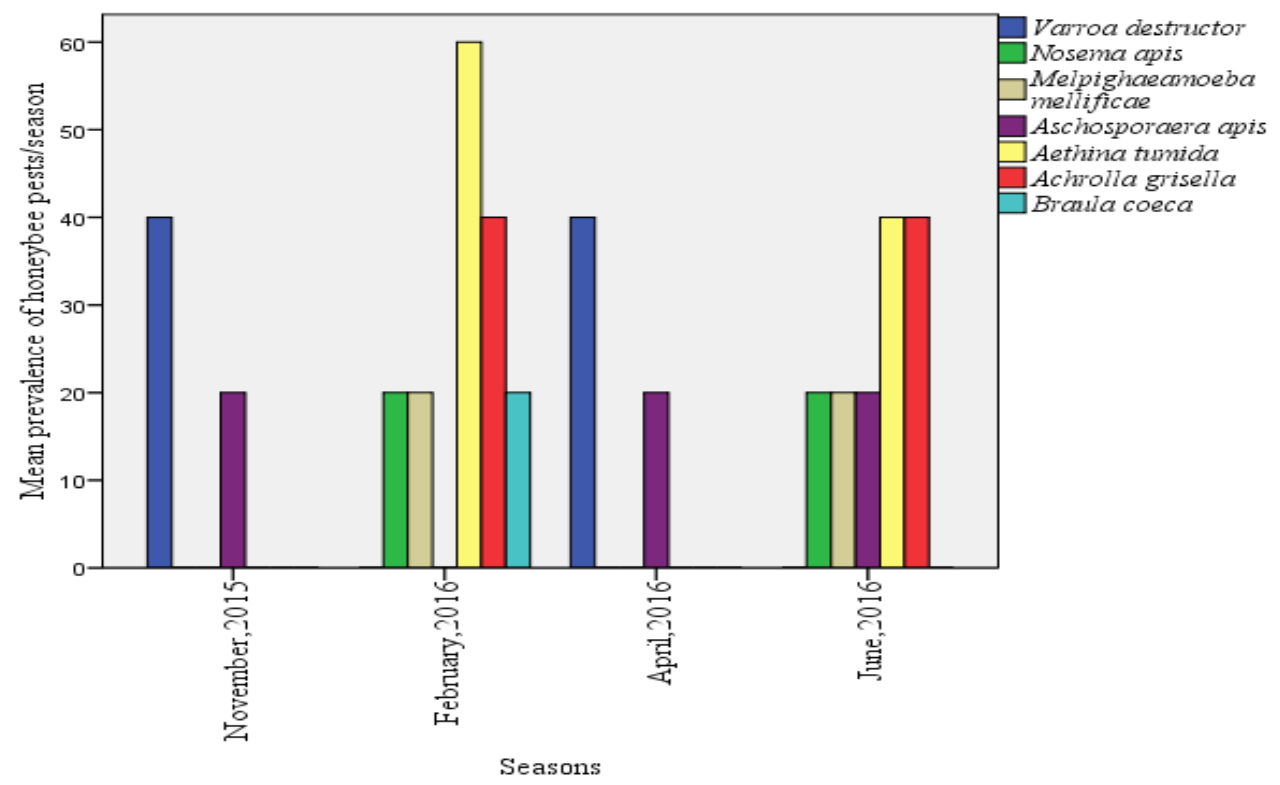

Figure2. Seasonal prevalence of honeybee pests, parasites and pathogens in Seka Chekorsa District

\subsection{Major Honeybee Pests' Prevalence Association to Some Risk Factors}

In this study, showing relatively elevated prevalence, Achrola grisella, Aethina tumida and Varroa destructor were described as the main honeybee pests (Table 4.4) The pests' prevalence has been studied in association with some potential risk factors: Altitude, Season, Hive types and strength of exposed honeybee colonies (Tables 4.5, 4.6 and 4.7 respectively). It was found that altitude, season, hive type and strength of honeybee colony are highly significantly $(\mathrm{P}<0.001)$ associated with prevalence of Achrola grisella (Table 4.5). Prevalence of Aethina tumida was significantly ( $\mathrm{P}<0.001)$ associated with altitude and season (Table 4.7). However, Varroa destructor prevalence was highly significantly $(\mathrm{P}<0.001)$ associated with altitude, season and honeybee colony strength (Table 4.8).In this study, there was not significant variation for both Aethina tumida and Varroa destructor as occurred in honeybee colonies of different categories (weak, moderate and strong) of strength which were established in different hive types. The fact that lack of honeybee forage and pollen sources is not as such a serious problem in the study area can support this result that honeybee colonies may relatively remain strong throughout the seasons resisting honeybee pests and parasites infestation. Even though, there is variation in honeybee colony strength based on subjective judgment, honeybee colonies remain with highest stamina to resist pests and parasites infestation.

Table4.5. Association of major risk factors to prevalence of Achrolla grisella in Seka Chekorsa District

\begin{tabular}{|c|c|c|c|c|c|c|c|}
\hline Variables & Categories & $\mathrm{N}$ & Count & $\begin{array}{l}\text { Positive Prevalence } \\
\text { (\%) }\end{array}$ & $X^{2}$ & df & P-value \\
\hline \multirow{3}{*}{ Altitude } & Highland & 60 & 6 & 23.1 & 1.459 & 2 & \\
\hline & Midland & & 6 & 23.1 & & & \\
\hline & Lowland & & 14 & 53.8 & & & $0.00 * *$ \\
\hline \multirow{4}{*}{ Season } & November,2015 & 60 & 8 & 30.8 & 1.473 & 3 & \\
\hline & February,2016 & & 5 & 19.2 & & & \\
\hline & April,2016 & & 6 & 23.1 & & & \\
\hline & June, 2016 & & 7 & 26.9 & & & $0.00 * *$ \\
\hline \multirow{3}{*}{ Hive types } & Traditional & & 6 & 23.1 & 1.502 & 2 & \\
\hline & Transitional & 60 & 11 & 42.3 & & & \\
\hline & Frame & & 9 & 34.6 & & & $0.00 * *$ \\
\hline \multirow{3}{*}{$\begin{array}{l}\text { Honeybee } \\
\text { population }\end{array}$} & Strong & & 8 & 30.8 & 1.477 & 2 & \\
\hline & Moderate & 60 & 8 & 30.8 & & & \\
\hline & Weak & & 10 & 38.5 & & & $0.00 * *$ \\
\hline
\end{tabular}

$N B: * *=$ highly significant 
Status of Honeybee Apismellifera Bandansii Pests and Pathogens in Seka Chokersa District of Jimma Zone, Ethiopia

Table4.6. Association of Major Risk Factors to Prevalence of Aethina tumida in Seka Chekorsa District

\begin{tabular}{|c|c|c|c|c|c|c|c|}
\hline Variable & Categories & $\mathrm{N}$ & Count & $\begin{array}{c}\text { Positive } \\
\text { prevalence (\%) }\end{array}$ & $\mathrm{X}^{2}$ & df. & P-value \\
\hline Altitude & Highland & 60 & 9 & 15 & 3.95 & 2 & \\
\hline & Midland & & 11 & 18.3 & & & $0.00^{* *}$ \\
\hline & Lowland & & 14 & 23.3 & & & \\
\hline Season & November,2015 & 60 & 13 & 24.1 & 1.473 & 3 & \\
\hline & February,2016 & & 5 & 19.2 & & & \\
\hline & April,2016 & & 15 & 27.8 & & & $0.00^{* *}$ \\
\hline Hive types & June,2016 & & 13 & 24.1 & & & \\
\hline & Traditional & 60 & 16 & 26.6 & 8.502 & 2 & 0.493 \\
\hline & Frame & & 18 & 33.3 & & & 2 \\
\hline $\begin{array}{c}\text { Honeybee } \\
\text { population }\end{array}$ & Strong & 60 & 18 & 33.3 & 14.320 & 2 & \\
\hline & Moderate & & 14 & 25.9 & & & 0.711 \\
\hline
\end{tabular}

Table4.7. Association of major risk factors to prevalence of Varroa destructor in Seka Chekorsa District

\begin{tabular}{|c|c|c|c|c|c|c|c|c|}
\hline Variables & Variable categories & $\mathrm{N}$ & Count & & $\begin{array}{c}\text { Positive } \\
\text { prevalence } \\
(\%)\end{array}$ & $\mathrm{X}^{2}$ & $\mathrm{df}$ & P-value \\
\hline Altitude & Highland & 60 & 8 & & 19 & 1.441 & 2 & \\
\hline & Midland & & 23 & & 54.8 & & & \\
\hline & Lowland & & 11 & & 26.2 & & & $0.00^{* *}$ \\
\hline Season & November,2015 & 60 & 11 & & 26.2 & 1.661 & 3 & \\
\hline & February,2016 & & 6 & & 14.3 & & & \\
\hline & April,2016 & & 13 & & 31 & & & \\
\hline & June,2016 & & 12 & & 28.6 & & & $0.00^{* *}$ \\
\hline Hive types & Traditional & 60 & 14 & & 33.3 & 15.023 & 2 & \\
\hline & Transitional & & 16 & & 38.1 & & & 0.923 \\
\hline $\begin{array}{c}\text { Honeybee } \\
\text { population }\end{array}$ & Frame & & 12 & & 28.6 & & & \\
\hline & Strong & 60 & 18 & & 42.9 & 15.641 & 2 & \\
\hline & Moderate & & 12 & & 28.6 & & & $0.00^{* *}$ \\
\hline
\end{tabular}

\subsection{Abundance of Varroa destructor in Different Hive Types}

Varroa destructor, a parasite of honeybee, is the most devastating pest mainly threatening bee keeping industry all over the globe (Allsopp, 2006; Gulati, Thakur, \& Giroh, 2013). Abundance/ intensity of Varroa destructor infestation in honeybee colony is more important factor to establish its management level in honeybee colonies (Delgado et al , 2012; Okosun, 2013). The intensity (Number of varroa destructor 100 bees) was compared in three hive types: Traditional, Transitional and Frame (Table 4.8). The result showed that, there is no significant variation $(\mathrm{F}=0.076, \mathrm{P}>0.05)$ in abundance/intensity of the mite among hive types. The overall mean Varroa destructor load was shown to be $1.13 \pm .24$ remaining well below maximum of mites/100 bees, the standard management range which is 2 mites/100 bees (OIE, 2011) indicating that honeybees are perhaps not affected by infestation of the mite in the studied honeybee colonies.

Table4.8. Mean comparison of Varroa destructor load in different hive types in Seka Cekorsa District

\begin{tabular}{|c|c|c|c|c|c|}
\hline \multirow[t]{2}{*}{ Hive types } & \multirow[t]{2}{*}{$\mathrm{N}$} & \multirow{2}{*}{ Mean+SE } & \multicolumn{2}{|c|}{$95 \% \mathrm{CI}$} & \\
\hline & & & Lower Bound & Upper Bound & $\mathrm{F}$ \\
\hline Traditional & 20 & $1.30 \pm .48$ & .82 & 1.78 & 076 \\
\hline Transitional & 20 & $1.20 \pm .43$ & .77 & 1.63 & \\
\hline Frame & 20 & $.90 \pm .34$ & .56 & 1.24 & \\
\hline Total & 60 & $1.13 \underline{13} .24$ & 1.06 & 1.37 & \\
\hline
\end{tabular}

$C I=$ Confidence interval $; F=F$-value $;$ Sig. $=$ significance value $;=$ number of sample; $S E=$ Standard error for mean 


\subsection{Correlation of Varroa destructor Load with Hive Variables}

In the current study, correlations of Varroa destructor intensity with some hive variables: age of honeybee colonies, amount of honey produced, and honeybee population was examined (Table 4.9). The result indicated that Varroa destructor intensity is not significantly $(\mathrm{P}>0.05)$ correlated with other hive variables except honeybee population strength $(\mathrm{P}<0.05)$. This has showed that Varroa destructor infestation level is not correlated with age of honeybee colonies, amount of honey produced. However, there is direct relationship between Varroa destructor infestation level and worker bee population where number of Varroa destructor/bee increases and so does worker honeybee population. This can show that the frequent brood rearing of honeybee colony can favor reproduction of honeybee Varroa destructor in hive while a colony build up can help keep the mites' load below economic threshold level. This result can also be supported by recent studies that mentioned varroa mite infestation could not bring significant effect on local honeybees (Elliud Muli, Harland Patch, 2014; Guesh Godfey, 2015).However, contrastingly, it is suggestive to think that the coupling of varroa destructor infestation in honeybees with another devastating pests like Achrolla grisella and Athina thumida as indicated in this study, may compromise resistance of honeybees and impact honey production. Therefore, it is recommended that future research should focus on ways to quantify effect of interaction of varroa mite with these potentially devastating honeybee pests.

Table4.9. Correlation of Varroa destructor load with some major hive variables in Seka Chekorsa District

\begin{tabular}{|l|l|l|l|l|l|}
\hline Hive variables & AHC (in years) & HP (in Kg) & NVM / 100 bees & HP \\
\hline \multirow{2}{*}{ AHC (in years) } & $\mathrm{R}$ & 1.000 & .010 & .013 & .027 \\
\cline { 2 - 6 } & $\mathrm{P}$ & & $.922 \mathrm{~ns}$ & .895 & .779 \\
\hline \multirow{2}{*}{ HPr. (in Kg) } & $\mathrm{R}$ & & 1.000 & .181 & .064 \\
\hline & $\mathrm{P}$ & & & .059 & .485 \\
\hline \multirow{2}{*}{$\mathrm{NVM} / 100$ bees } & $\mathrm{R}$ & & & 1.000 & \\
\cline { 2 - 6 } & $\mathrm{P}$ & & & & $.027^{*}$ \\
\hline \multirow{2}{*}{ HPo. } & $\mathrm{R}$ & & & & 1.000 \\
\hline & $\mathrm{P}$ & & & &. \\
\hline
\end{tabular}

$N s=$ Correlation is not significant at 0.01; $R$ is Pearson Correlation coefficient; $P$ is $P$-value; Kg is kilogram; HPr is honey production in kilogram; NVM is number of varroa mite/loo bees; and HPo is honeybee population.

\subsection{Varroa destructor Enhances Prevalence of Aethina tumida and Achrolla grisella in honeybee}

The prevalence of honeybee pests, Aethina tumida and Achrolla grisella, was examined under multiple hive infection state and their association with Varroa destructor, which is a recently introduced honeybee parasite into the country (Desalegn Begna, 2015b).Studies have suggested that honeybee pests like Aethina tumida, Achrolla grisella and Varroa destructor are extensively blamed for massive loss of honeybees globally (Christian et al, 2015; Wolfgang and Ute, 2016). By the result, it was showed that the prevalence of both Aethina tumida and Achrolla grisella has been positively enhanced in Varroa destructor positive hives $\left(\mathrm{OR}=2.6 ; \mathrm{X}^{2}=5.53\right.$; lower limit $=.78$; upper limit= 8.59; $\mathrm{P}<0.05$ ) as compared to the mite free hives (Figure.4.9).The result has also demonstrated that comparatively the prevalence of Aethina tumida (40.27\%) is much more greater than that of Achrolla grisella $(18.58 \%)$.Recent study has evidenced that honeybee colonies infection by combined pests and parasites can deteriorate the potency of honeybees than single infection (Ahmed and Abdalla Elniweiri, 2016).From this testing it is evident to advise that a detailed research should consider multiple infection in honeybee colonies to broadly quantify the effect of this on honeybees and hive products. 


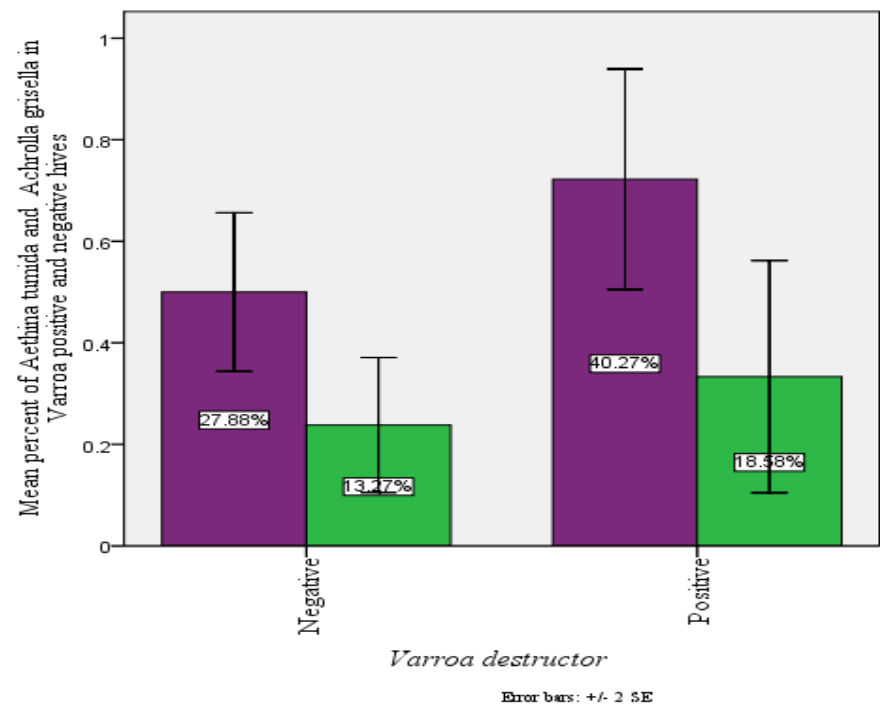

Aethina tumida Achrolla grisella

Figure3. Mean+SE percent (rate) comparison of prevalence of Aethina tumida and Achrolla grisella in Varroa destructor positive and Varroa destructor negative honeybee colonies in Seka Chekorsa

NB: 'OR' is odd ratio of prevalence of Aethina tumida and Achrolla grisella in presence (positive) and absence (negative) states of hives with Varroa destructor; ' $\mathrm{X}^{2}$ ' is a Pearson chi-square coefficient of association; and ' $\mathrm{P}$ ' is a $\mathrm{P}$-value.

\subsection{Comparison of Honeybee Pests versus Hive population and Honey Production}

Comparison of honeybee population growth and corresponding honeybee production trends in pest free and pest affected sample hive types (Traditional, Transitional and Frame) in each season has been given in Figure.4.10 and Figure.4.11 respectively. The result shows that, regardless of hive types, there was noticeable decrease for both honeybee population growth (Figure.4.10) and honey production (Figure.4.11) between honeybee pest free and pest affected honeybee colonies along the seasons. However, normal seasonal pattern in honeybee population growth and honey production, in both pest free and pest affected honeybee colonies, was showed to not have been changing. At the same time, it was revealed that there had been honey harvest throughout all the seasons with considerable max out in autumn (November) and spring (April) seasons in both pest free and pest affected honeybee colonies. Therefore, this could be taken as basic evidence to infer that the pest influx in honeybee colony may not change honey production and honeybee population build up patterns; but reduce honeybee population and honey production. It has been forecasted that infections with honeybee pests and pathogens are known to cause reduced lifespan of individual bees, reduced performance of colonies, and increased winter mortality (Fries, 2015).

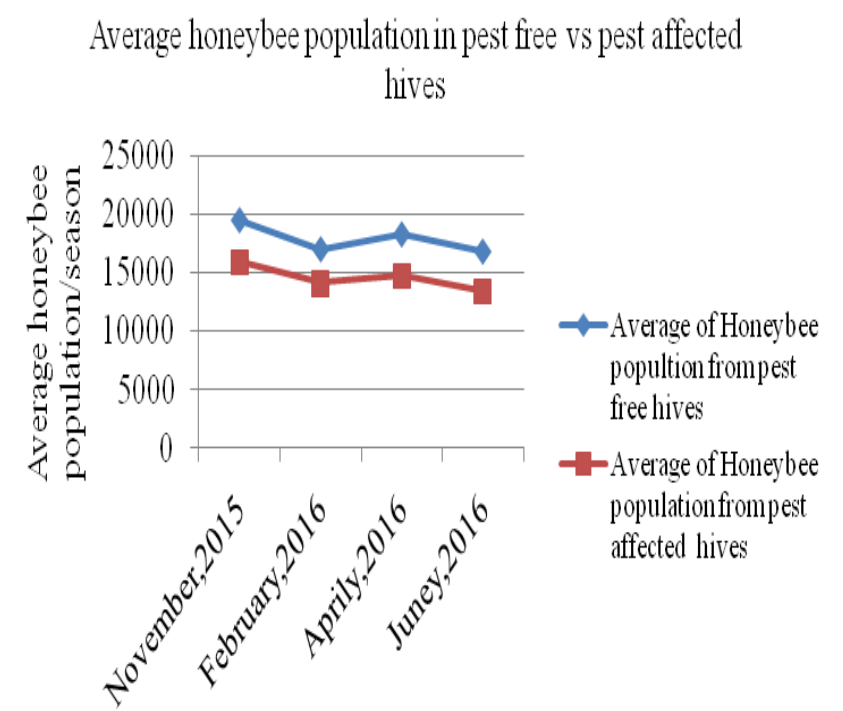

Figure4. Honeybee population in honeybee pest free and honeybee pest infested hives in Seka Chekorsa District 
Average honey produced from pest free pesst affected all hive types

per season

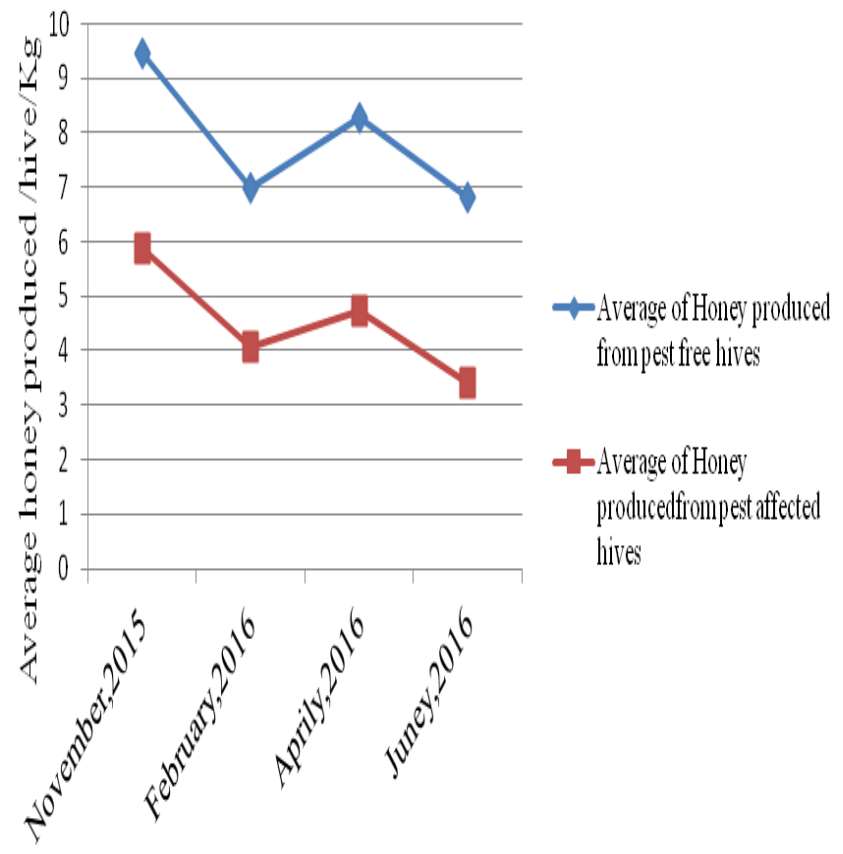

Figure5. Honey produced in honeybee pest free and honeybee pest infested hives in Seka Chekorsa District

\section{CONCLUSION AND RECOMMENDATION}

Despite tremendous potential, it have been alerted that honey and bees wax production is on the pace to shrink in Ethiopia (Optimal Solutions Group, 2002; Yirga et al, 2012;Tolera Kumsa and Dejene Takele, 2014). Studies have put forward that a combination of different factors and enemies might constrain honeybees and beekeeping activity in the country (Gidey Yirga et al , 2010; Kinati et al., 2012; Tolera Kumsa and Dejene Takele, 2014).However studies have been few to describe types of existing practical problems and enemies. This study has paid close attention to investigate general honeybee problems with special emphasis on diagnosing pests, parasites and pathogens and potential risk factors in Seka Chekorsa district. It was known that honeybee health constraints in the district are diverse. The major constraints identified are honeybee pests and pathogens, prevailing bad weather, poor or absence of seasonal hive management; application of agrochemicals. However, honeybee pests and parasites are remarked as the most problems causing absconding of honeybee colonies.

The fact that prevalence's of major honeybee pests is affected by agro ecological difference and seasonal variation suggests future management strategies of each honeybee pests should take in to account these variables in the area. However, variation in factors like hive types and strength of hive population was found to be not a concern to change infestation level of most of honeybee pests $(\mathrm{P}>0.05)$. Indeed, it is proposed that before examining association of these risk factors to prevalence of the studied honeybee pests, honeybee population be measured and estimated under controlled condition where other external factors can be kept at minimal. Varroa mite prevalence is significantly varied with strength of hive population. But future studies should take a note that coupling of the mite other potentially devastating honeybee pests may compromise the immunity of honeybees thereby impacting honey production.

The other honeybee pests, parasites and pathogens (bacterial diseases: Paenibacillus larvae and mellissococcus pluton); fungal pathogens (Aspergillus flavus); and parasitic mites (Acarapis woodii) whose incidence has generally been perceived minimal or negligible in most tropical beekeeping regions were not established during this study for which reason this study has to limit itself to report it as a concrete evidence of total absence of these honeybee pests, parasites and pathogens in the country. Fairly, it is suggested that specific and wide-ranging study be conducted in the future to declare the absence of these honeybee parasites and pathogens to support this study be complete to the best of its farsighted purpose. 
It is worth noting that this study could be able to explored general information about available constraints of honeybee health and make it helpful in the logic that it has documented major honeybee pests and parasites together with the extent of their prevalence in honeybee colonies, and associated risk factors in the study area. Hence, it can render basic information for beekeepers, honeybee experts, researchers, NGOs and policy makers in designing any of their research and development endeavors in beekeeping and honeybee health.

From the above conclusion, the following recommendations are forwarded for future research and development of beekeeping and honeybee health.

* In the study area, some honeybee pests and parasites are much prevalent than the other at honeybee colony level, but the particular reason for this variability is not known. Therefore, future research should focus on investigating the reason why some honeybee pests have higher prevalence in infesting honeybees than the others.

* Therefore, beekeepers should keep the hygiene of their apiaries and should be trained on pest and disease transmitting routes for better seasonal management of honeybees. Also, beekeepers should have knowledge in identifying honeybee parasites to produce immediate and trustworthy data for future honeybee health research and modeling plans.

* We recommend a more controlled study to be conducted to establish a minimum/tolerable infestation level for those honeybee pests, parasites and diseases reported to be prevalent in the current study area.

* Factors like agro ecology, season, hive type and honeybee colony strength affects prevalence of most honeybee pests and need to be considered in seasonal honeybee management plans.

* Some honeybee pathogens of low likelihood of existence in the country like American foulbrood, European Foulbrood, Tracheal Mites, Stone Brood were not tested positive during this study. Therefore, a pest specific and large scale research is recommended to be sure that these honeybee pathogens and pests are absent in the current study area in particular and in the country in general.

\section{REFERENCES}

Abebe Alemu, Gemeda Abebe, Wonde wossen Tsegaye, Lemu Golassa (2011). Climatic Variables and Malaria Transmission Dynamics in Jimma Town, South West Ethiopia, Parasites \& Vectors, 4(1), 30-47.

Adeola A. O., Bifarin J., \& FolayanJ. A. (2011). Honey Marketing in Ibadan Metropolis of Oyo State, Nigeria : An Economic Analysis, 2(2), 113-119.

Ahmed, M. (2016). First report of Apis florea in Ethiopia 6 th COLOSS Conference Prevention of Honey Bee COlony LOSSes. In VI ${ }^{\text {th }}$ COLOSS Conference-Ankara, Turkey-5-6- September 2010.

Allsopp M. (2006). Analysis of Varroa Destructor Infestation of Southern African Honeybee Populations.Dissertation submitted in fulfilment of the requirements for the degree of Master of Science. University of Pretoria Pretori.

Allsopp. M. (2006). Analysis Of Varroa Destructor Infestation of Southern African.

Botías C., Martín-hernández R., Barrios L., Meana A. \& Higes M. (2013). Nosema spp . infection and its negative effects on honey bees (Apis mellifera iberiensis ) at the colony level Nosema spp . infection and its negative effects on honey bees (Apis mellifera iberiensis) at the colony level. Veterinary Research, 44:25,11-16.

Bronisław K. et al. (2000). Temperature-dependent regulatory mechanism of larval development of the wax moth (Galleria mellonella). Acta Biochimica Polonica, 47:1, 215-221.

Cepero A., Ravoet J., Gómez-moracho T., Bernal J. L., Nozal M. J. D., Bartolomé C., Higes M. (2014). Holistic screening of collapsing honey bee colonies in Spain : a case study. Biomed Central, 1:7, 1-10.

Chala Kinati, Taye Tolemariam, Kebede Debele and Tadele Tolosa. (2012). Opportunities and challenges of honey production in Gomma district of Jimma zone, South-west Ethiopia, Journal of Agricultural Extension and Rural Development, 4:4, 85-91.

CSA (2014). Key Findings of 2013/2014 Agricultural Sample Survey.A Report, Central Statisticl Agency,Addis Ababa,Ethiopia.pp.24.

Delgado D. L., Galindo-cardona A., Giray T. \& Restrepo C. (2012). Forecasting the Influence of Climate Change on Agroecosystem Services : Potential Impacts on Honey Yields in a Small-Island Developing State, Hindawi Publishing Corporation, 2012,1-10. 
Desalegn Begna Rundassa. (2001). Chalk brood in ethiopia. Bees for Development Journal 78, 78. 16-24.

Desalegn Begna. (2015). Occurrences and Distributions of Honeybee ( Varroa mite) Apis mellifera Jemenetica ) ) in Tigray Region, Ethiopia. Journal of Fisheries \& Fisheries Livest Production, 3:1, 1-4.

Elliud M., Harland Patch, M. F. (2014). Evaluation of the Distribution and Impacts of Parasites, Pathogens, and Pesticides on Honey Bee (Apis mellifera) Populations in East Africa. Retrieved from (http://www.nsf.gov/bio/bread/index.jsp on 16 of June,2016.

El-niweiri M. A. A. \& Satti, A. A. (2008). Status quo of honeybee ( Apis mellifera L .) pests and diseases in Sudan, Apicata, 1985(July), 6-12.

Ephrem Tesema. (2013). Zonal Diagnosis and Intervention Plan Report for Jimma Zone A research report,LIVES Project,International Livestock Research Institute,Ethiopia.pp.74.

Gidey Yirga and Mekonen Teferi (2010). Participatory Technology and Constraints Assessment to Improve the Livelihood of Beekeepers in Tigray Region , northern Ethiopia. MEJS, 2:1, 76-92.

Gidey Yirga, Bethelhem Koru, D. K. and A. M. (2016). Assessment of beekeeping practices in Asgede Tsimbla district, Northern Ethiopia: Absconding, bee forage and bee pests Assessment of beekeeping practices in Asgede Tsimbla district, Northern Ethiopia: Absconding, bee forage and bee pests. African Journal of Agricultural Research, 7:1 (May), 1-5.

Gidey Yirga, Bethelhem Koru, Dawit Kidane and Alem Mebrahatu (2012). Assessment of beekeeping practices in Asgede Tsimbla district, Northern Ethiopia : Absconding, bee forage and bee pests, African Journal of Agricultural Research,7:1, 1-5.

Haylegebriel Tesfay (2014). Honey Bee Diseases, Pest and Their Economic Importance in Ethiopia. International Journal of Innovation and Scientific Research. a, 10:2, 527-535.

Hornitzky, M. (2008). Literature review and three year survey of beekeepers Part. Research Journal of Agriculture and Environmental Management, 2(08).

Hornitzky M. (2008). Nosema Disease. Retrieved from http://www.rirdc.gov.au, on $27^{\text {th }}$ of January,2013.

Hussein M. H. (2000). Beekeeping in Africa:I. North, East, North-East and West African countries. Apiacta, $1: 3,2-48$.

Jacquetta. (2013). Declining Bee Numbers Measures to Protect the Pollinators in Africa and Asia.

Karimi N. R. (2010). A Survey of Nosema of Honey Bees (Apis mellifera) in East Azarbaijan Province of Iran. Journal of Animal and Veterinary Advances, 95 , 879-

Neuman P. (2009). Scientific Report submitted to EFSA Bee Mortality and Bee Surveillance in Europe. Pascal Hendrikx - AFSSA - France, (178), 56-97.

Neumann P. \& Carreck N. L. (2010). Honey bee colony losses. Journal of Apicultural Research, 49:1, 1-6.

Neumann P. \& Carreck N.L. (2010). Honey bee colony losses. Journal of Apicultural Research, 49, 1-6.

Optimal Solutions Group. (2002). Cost-Benefit Analysis of the Honey Value Chain in Ethiopia Graduation with Resilience to Achieve Sustainable Development.Grad Project Final Report (pp. College Park, MD 20740 USA. pp.35

Paudel Y. P., Mackereth R., Hanley R. \& Qin W. (2015). Honey Bees ( Apis mellifera L .) and Pollination Issues: Current Status, Impacts, and Potential Drivers of Decline, Journal of Agricultural Science ,7:6, 93-109.

Retschnig, G. (2015). Methods in honey bee research.Agroscope,1 (July), 1-19.

Robert K., Jacob G. A., Donald R .K., Victor A. and Arah A. O. (2009). National Beekeeping Calendar, Honeybee Pest And Disease Control Methods For Improved Production. A Research Report, National Agricultural Research Orgnization,Entebbe,Uganda.pp.62.

RoseR., Pettis J. \& RennichK. (2014). A US national survey of honey-bee pests and diseases, The OIE aand its Partners (1), 71-74.

Sihag, R. C. (2014). Phenology of Migration and Decline in Colony Numbers and Crop Hosts of Giant Honeybee ( Apis dorsata F .) in Semiarid Environment of Northwest India. Journal of Insects, 2014(NA), 30-67.

Tarpy.J . (1998). The Small Hive Beetle: A Pest of Honey Bee Colonies. Golden LEAF Foundation. North Carolina Cooperative Extension Service.pp.29.

Tessega Belie. (2009). Honeybee Production and Marketing Systems, Constraints and Opportunities in Burie District of Amhara Region,Ethiopia. Bahir Dar University.pp.131.

Tolera Kumsa and Dejene Takele. (2014). Assessment of the effect of seasonal honeybee management on honey production of Ethiopian honeybee ( Apis mellifera ) in modern beekeeping in Jimma Zone. Research Journal of Agriculture and Environmental Management, Research Journal of Agriculture and Environmental Management, 3:5, 246-254. 
Wanjama J K, Onyango I, Mutyambai D M, K. S. K. and N. P. N. (2016). Occurrence of Nosema Species In Honey Bee Colonies In Kenya. In Animal Health and Production in Africa (pp. 37-38). Nairobi,Kenya.

Yetimwork Gebremeskel. (2015). Honeybee production trend, potential and constraints in Eastern Zone of College Tigray. Agriculture And Biology Journal Of North America, 6:1, 22-29.

Citation: D. Gemedi, "Status of Honeybee Apismellifera Bandansii Pests and Pathogens in Seka Chokersa District of Jimma Zone, Ethiopia", International Journal of Research Studies in Biosciences (IJRSB), vol. 5, no. 12, pp. 12-27, 2017. http://dx.doi.org/10.20431/2349-0365.0512003

Copyright: (C) 2017 Authors. This is an open-access article distributed under the terms of the Creative Commons Attribution License, which permits unrestricted use, distribution, and reproduction in any medium, provided the original author and source are credited. 